\title{
Contents, Vol. 39, 1977
}

\section{Contents}

No. 1

Toppozada, H.H.; Gaafar, H.A., and El-Ghazzawi, E.F.: The Role of Plasma Cells in Scleroma. Electron-Microscopic Study 1

Bleeker, J.D. and Edens, E.T.: Viral Lesions of the Respiratory Tract Compared to Iatrogenic Trauma 14

Society Transactions · Gesellschaftsberichte •Comptesrendusdesociétés

Schweizerische Gesellschaft für Oto-Rhino-Laryngologie, Hals- und Gesichtschirurgie

Société Suisse d'Oto-Rhino-Laryngologie et de Chirurgie Cervico-Faciale Società Svizzera di Oto-Rino-Laringologia e di Chirurgia Cervico-Faciale 63. Wissenschaftliche Frühjahrsversammlung gemeinsam mit der Österreichischen Gesellschaft für Hals-Nasen-Ohrenheilkunde, Kopf- und Halschirurgie, Basel, 30. Mai bis 2. Juni $1976 \quad 23$

No. 2

Poulsen, G. and Tos, M.: Tubal Function in Chronic Secretory Otitis media in Children 57 Edström, S.; Lundin, K., and Jeppsson, P.-H.: Secretory Otitis media. Aspects on Treatment and Control 68

Takahashi, M.; Igarashi, M., and Homick, J.L.: Effect of Otolith End Organ Ablation on Horizontal Optokinetic Nystagmus, and Optokinetic Afternystagmus in the Squirrel Monkey 74

Rodenburg, M. and Maas, A.J.J.: Psychophysical Determination of the Phase Characteristic of the Vestibular System of Man for Sinusoidal Oscillation in Yaw .... 82

Benitez, J.T.: Stapedectomy and Fatal Meningitis. A Human Temporal Bone Study . . 94 Dijkstra, B.K.S.: Goldenhar's Syndrome, Oculo-Auricular Malformation, in a Bantu Girl 101

Albegger, K.W.: Cluster Formation in Human Nasal Polyps. A Light- and ElectronMicroscopic Investigation 107

Contents IV

Harada, Y.; Sasaki, H., and Gaafar, H.: The Effect of an Expectorant on the Tracheal Mucosa. A Scanning-Electron Microscopic Study 113

Månsson, I.: Influence on Flow Resistance in Translaryngeai Tubes and Tracheostomy

Tubes by Bronchofiberscope 122

Book Review 127

Varia 128

No. 3

Rossi, G.: Automatic Audiometry in Stapes Motility Evaluation 129

Kumagami, H. and Níshida, H.: Diagnostic Significance of Summating Potential in Sensorineural Deafness 
Hoogland, G.A.: The Facial Nerve Coursing across the Oval Window Area

Petruson, B.; Rudin, R., and Svärdsudd, K.: Is High Blood Pressure an Aetiological

Factor in Epistaxis? 155

Åhrén, C. and Lindstrôm, J.: Adenomatosis of Accessory Salivary Glands of the Lip.

Report of Two Cases ,. 161

Society Transactions

Nederlandse Keel-Neus-Oorheelkundige Vereniging. 143ste Vergadering te Leiden, 15 en 16 oktober 1976 - Dutch Oto-Rhino-Laryngological Society. 143rd

Meeting, Leiden, October 15 and 16, 1976167

Nederlandse Keel-Neus-Oorheelkundige Vereniging. 144ste Vergadering Antoni van

Leeuwenhoekziekenhuis, Amsterdam, 15 en 16 april 1977 - Dutch Oto-Rhino-Laryngological

Society. 144th Meeting, Amsterdam, April 15 and 16, 1977176

Book Reviews 182

Varia 184

No. 4

Podvinec, M.: Electroneuronography in Prognosis of Intratemporal Facial Palsy, as

Compared to Measurements of Rheobase and Chronaxy 185

Kato, I.; Miyoshi, T., and Pfaltz, C.R.: Studies on Habituation of Vestibulospinal Reflexes.

Effects of Repetitive Optokinetic and Vestibular Stimuli upon the

Stepping Test 195

Boniver, R. and Demanez, J.P.: Interest of the Study of the Influence of Ocular

Fixation during Caloric Tests in Pontocerebellar Tumors 203

Takemori, S. and Suzuki, M.: Cerebellar Contribution to Oculomotor Function .... 209

Tos, M.: Combined Grafts in Total Reconstruction of Old Radical Cavities 218

Feinmesser, M.; Tell, L., and L·evi, C: Screening for Hearing Impairment in Early

Childhood 227

Kelemen, G.: Morquio's Disease and the Hearing Organ 233

Elverland, H.H.; Mair, I.W.S., and Borud, O.: Hereditary Deafness in the Cat. Free

Amino Acid and Sugar Content in the Perilymph 241

Contents V

Onuigbo, W.I.B.: Cancer of the Oral Cavity in Nigerian Igbos 247

Taylor, R.F.: Late Recurrence of Cancer in the Larynx and Hypopharynx after Irradiation 251

No. 5

Devriese, P.P.: Prednisone in Idiopathic Facial Paralysis (Bell’s Palsy) 257

Eneroth, C.-M.; Andreasson, L.; Beran, M.; Biörklund, A.; Carlsöö, B.; Modalsli, B.'’ Olofsson, J.; Paavolaínen, M., and Toll, B.: Preoperative Facial Paralysis in

Malignant Parotid Tumors 272

Leth, N. and Tos, M.: Middle Ear Ventilation after Acute Otitis media 278

Rosenhall, U.; Nyman, H., and Stahle, J.: Vestibulotoxic Effect of Alkylating Agents . 285

Mizukoshi, K. andPfaltz, C.R.: The Influence of Optokinetic Training upon Vestibular

Responses Induced by Repetitive Sinusoidal Stimuli 292

Book Reviews $\quad 305$

Varia 308

No. 6

Pfaltz, C.R. and Novak, B.: Optokinetic Training and Vestibular Habituation 
Takahashi, M. and Igarashi, M.: Comparison of Vertical and Horizontal Optokinetic Nystagmus in the Squirrel Monkey 321

Taguchi, K.: Spectral Analysis of Body Sway 330

Hoogland, G.A. and Marres, E.H.M.A.: The Facial Nerve Coursing across the Promon tory with a Persistent Stapedial Artery 338

Society Transactions

Nederlandse Keel-Neus-Oorheelkundige Vereniging. 145ste Vergadering te Ut recht, 28 and 29 oktober 1977 - Dutch Oto-Rhino-Laryngological Society. 145th

Meeting, Utrecht, October 28 and 29, 1977342

Varia 349

Subject Index 350

Author Index 355 